\title{
Carrier-Free Immobilization of Rutin Degrading Enzyme Extracted From Fusarium spp.
}

\author{
Yuan-Yuan Zang ${ }^{1 \dagger}$, Sha Yang ${ }^{1 \dagger}$, Yong-Qiang $X u^{2}$, Zhi-Gang Chen ${ }^{1 *}$ and Tao $\mathrm{Wu}^{3}$ \\ ${ }^{1}$ Glycomics and Glycan Bioengineering Research Center, College of Food Science \& Technology, Nanjing Agricultural \\ University, Nanjing, China, ${ }^{2}$ College of Life Science and Engineering, Lanzhou University of Technology, Lanzhou, China, \\ ${ }^{3}$ Department of Food Science, University of Tennessee, Knoxville, Knoxville, TN, United States
}

\section{OPEN ACCESS}

Edited by:

Jesús Fernández Lucas, Universidad Europea de Madrid, Spain

Reviewed by: Jian Dong Cui, Hebei University of Science and Technology, China Sachin Talekar, IITB-Monash Research Academy, India

*Correspondence:

Zhi-Gang Chen

zgchen@njau.edu.cn

tThese authors have contributed equally to this work

Specialty section:

This article was submitted to Bioprocess Engineering,

a section of the journal Frontiers in Bioengineering and Biotechnology

Received: 23 February 2020 Accepted: 22 April 2020 Published: 26 June 2020

Citation:

Zang $Y-Y$, Yang $S, X u Y-Q$, Chen $Z-G$ and Wu T (2020) Carrier-Free Immobilization of Rutin Degrading Enzyme Extracted From Fusarium spp. Front. Bioeng. Biotechnol. 8:470. doi: 10.3389/fbioe.2020.00470
In this study, a strain with rutin degrading enzyme (RDE) activity was screened from moldy tartary buckwheat and subsequently identified as Fusarium spp. The structure and enzyme characteristics of CLEA-RDE formed by immobilization via cross-linking were then investigated. Further, the optimal catalysis conditions of CLEA-RDE in natural deep eutectic solvents (NADESs) serving as hydrolysis solvents were also investigated. The results of SEM and spectrum indicated that CLEA-RDE became more stable than free-RDE due to the cross-linking. Interestingly, CLEA-RDE showed a wider range of $\mathrm{pH}$ adaptation and higher tolerance to low temperatures $\left(20-30^{\circ} \mathrm{C}\right)$ and hydrophobic environments. The results of orthogonal experiments revealed that the optimal condition for rutin hydrolysis was under $\mathrm{pH} 5.0$ and $40^{\circ} \mathrm{C}$ with the degradation rate of $10.65 \mathrm{mg}$ $\mathrm{min}^{-1} \mathrm{~L}^{-1}$. The preparation of CLEA-RDE without a carrier-based immobilization method reduces the loss of enzyme activity, improves the stability of the enzyme and can be applied to the investigation of immobilization of various enzymes, thus providing a referred idea for the improvement of catalysts in industrial production.

Keywords: fusarium, rutin degrading enzyme (RDE), cross-linked enzyme aggregate (CLEA), natural deep eutectic solvents (NADESs), enzymatic characteristics

\section{INTRODUCTION}

Quercetin is a polyhydroxy flavonoid compound with a chemical name of $3,3^{\prime}, 4^{\prime}, 5$, 7-pentahydroxyflavone (Ulusoy and Sanlier, 2019) which is common in nature and is found in many foods such as onion, green tea and asparagus (Alinezhad et al., 2011; Nishimuro et al., 2015). It has various pharmacological effects, such as antioxidant effects (Simioni et al., 2018), preventing cardiovascular disease, and inhibiting the metabolism of cancer cells. In addition, quercetin is an efficacious substance in treating diabetes, neurological diseases, and obesity.

Rutin degrading enzyme (RDE), which can specifically convert rutin to quercetin, was first discovered by a Japanese scientist Yasuda Toshitaka from tartary buckwheat in 1993 (Yasuda and Nakagawa, 1994). Currently, chemical catalysis is normally used to obtain quercetin from rutin (Biesaga et al., 2007; Wach et al., 2007), which is not an environmentally benign process for such a low yield. In contrast, RDE catalysis is considered as a milder, greener and more efficient way to prepare quercetin from rutin. Tartary buckwheat (Yasuda and Nakagawa, 1994), hypericum perforatum (Biesaga et al., 2007), and onion (Turner et al., 2006) could be good sources of RDE.

Modern industry has been working to improve the stability of enzymes by immobilization (Liang et al., 2019). However, traditional immobilization methods are usually in need of an additional 
carrier which leads to a dilution or even loss of catalytic activity due to the complicated process (Bryjak and Kolarz, 1998; Tischer and Kasche, 1999). Therefore, carrier-free immobilization is beginning to get people's attention. Among them, CLEA has been proven to be a more effective method because it avoids the loss of origin activity, improves the catalytic efficiency (Cao et al., 2000) and stability to $\mathrm{pH}$, temperature (Bian et al., 2019; Kulkarni et al., 2019; Talekar et al., 2020) and organic solvents (Cui et al., 2012, 2017; dong Cui et al., 2014; Cui and Jia, 2015; Bian et al., 2019; Razib et al., 2020). It is also easy to prepare and does not require high-purity enzymes, which means that different types of enzymes can be cross-linked at the same time (Mateo et al., 2004). There are two steps to prepare CLEA: Firstly, physical aggregates are obtained by changing the proximity between soluble enzyme molecules through changing the hydration state or altering the electrostatic constant of the solution through adding appropriate aggregation agents. Secondly, the cross-linking was performed using a bi-functional cross-linker to form CLEAs (Cao et al., 2003). So far, CLEA has been successfully used to immobilize many enzymes (Schoevaart et al., 2004; Talekar et al., 2012, 2014; Cui et al., 2016).

A previous study suggested that enzymes had good catalytic activity in non-aqueous or micro aqueous systems (Talekar et al., 2013). Recent studies found that the trace water preserved the active structure and improved the stability (Klibanov, 1986). Additionally, the substrate solubility was improved, and the side reactions were inhibited, which may have shifted the thermodynamic equilibrium to a desired direction (Zaks and Klibanov, 1984; Dordick, 1989). According to previous research (Zang et al., 2020), NADESs is a new kind of non-aqueous solvent, which inherits the excellent characteristics of ionic solvents and moreover process unique advantages of low toxicity, biodegradability, easy synthesis, and recycling.

In this study, strains containing RDE from moldy tartary buckwheat were screened. And we employed a novel, carrierfree immobilization method to form CLEA-RDE by altering the electrostatic constant of the solution and cross-linking through an addition of $25 \%$ glutaraldehyde solution. The activity and stability of this kind of enzyme were subsequently determined and compared with free-RDE. Finally, the effects of NADESs on promoting the catalytic activity of CLEA-RDE were also investigated.

\section{MATERIALS AND METHODS}

\section{Chemical and Biological Materials}

The tartary buckwheat was purchased from a local market in Sichuan province, China. Rutin standard was obtained from Beijing Bailingwei Technology Co., Ltd. Bovine serum albumin, choline chloride, glycerol, ammonium sulfate, glutaraldehyde, tris, hydrochloric acid, dimethyl sulfoxide, methyl alcohol, ethyl alcohol, and trichloromethane were purchased from Aladdin Chemical Reagent Co., Ltd. (Shanghai, China). Ethidium bromide and DL2000 DNA Marker were purchased from Solarbio Life Science Co., Ltd. (Beijing, China). PCR amplification primers were synthesized by General Biosystems Co., Ltd. (Anhui, China). Agarose and gel cutting recovery kits were purchased from Sangon Biotech Co., Ltd. (Shanghai,
China). DNA extraction kits were purchased from SparkJade Scientific Instruments Co., Ltd. (Shandong, China).

\section{Preparation of Major Reagents Preparation of NADESs}

NADESs that are suitable for RDE catalysis were selected from the literature (Zang et al., 2020). Choline chloride and glycerol were weighed at a molar ratio of $1: 1$ and then mixed at $200^{\circ} \mathrm{C}$ until a homogeneous liquid was formed. Then it was mixed with deionized water at a ratio of 80:20 (V/V) before use.

\section{Preparation of Media}

Acclimation medium: a liquid Czapek-Dox medium was modified by adding rutin $(0,2,4,6,8,10 \mathrm{~g} / 50 \mathrm{~mL})$ as a carbon source and correspondingly reducing the amount of sucrose accordingly (10, 8, 6, 4, 2, $0 \mathrm{~g} / 50 \mathrm{~mL})$.

Separation medium: solid Czapek-Dox medium.

Identification medium: Modified liquid Czapek-Dox medium by replacing sucrose with rutin, other ingredients remain unchanged.

\section{Source and Domestication of Strain}

Organism suspension: weighed $10 \mathrm{~g}$ moldy buckwheat flour (mold at $25^{\circ} \mathrm{C}$ with a relative humidity of $50 \%$ for 3 days), dissolved in $200 \mathrm{~mL}$ of distilled water and then filtered for standby.

Inoculation: added $200 \mu \mathrm{L}$ of suspension to sterilization medium.

Acclimation: Acclimate the strains in the medium with increasing rutin content. Five days is a period, and culture in a shaker at $28^{\circ} \mathrm{C}$ at a speed of $200 \mathrm{r} / \mathrm{min}$. At the end of each cycle, $200 \mu \mathrm{L}$ of the culture suspension was inoculated into the medium of next cycle, and the operation was repeated until the strain growth was stable.

\section{Isolation and Purification of Strains}

Refer to GB 4789.16-2016 (GB 4789.16-2016, 2017), domesticated strains were isolated and purified by streak plate method, and then the plates were cultured at $28^{\circ} \mathrm{C}$ Repeated the above procedures until single strain was obtained and picked for liquid culture.

\section{Identification of Strain Activity}

Two hundred Microliters of each organism solution was taken and inoculated in the identification medium, $28^{\circ} \mathrm{C}, 200 \mathrm{rpm}$ for $3 \mathrm{~d}$. Organism suspension was then centrifuged at $4000 \mathrm{r} / \mathrm{min}$ for $5 \mathrm{~min}$, and the rutin amount in the supernatant was determined by HPLC as described in former study (Zang et al., 2020).

\section{Strain Preservation}

The selected strain was inoculated and cultured at $30^{\circ} \mathrm{C}$ for $2-3$ $\mathrm{d}$, and then stored in a $4^{\circ} \mathrm{C}$ refrigerator.

\section{Strain Identification Morphological Identification}

Morphological observation: The isolated strains were inoculated into the Czapek-Dox medium with the spot planting method and cultured at $28^{\circ} \mathrm{C}$ for 5 days. During this period, the morphology of the colonies was observed and recorded. 
Micro-structural observation: dropped a small drop of Lactobacillus carbonate cotton blue dye on the slide, took a small amount of mycelium and rinsed it in $50 \%$ ethanol solution, then washed the soaked mycelium with distilled water once, then immersed it in the dye solution, and covered the slide. They were observed under a 10, 20, 40, and 100 times optical microscope, and finally observed and recorded under 100 times oil microscope, for a preliminary identification of the organism, referring to Wei (1979).

\section{Molecular biological identification}

The purified strain was cultured on a flat plate with cellophane at $28^{\circ} \mathrm{C}$ for $3 \mathrm{~d}$. The cultured fungal tissue was put into a mortar and ground into fine powder with liquid nitrogen. The DNA of the strain was extracted by SPARKeasy Fungus DNA kit.

PCR amplification of ITS rDNA target fragment was conducted as follows:

a) The primer sequence is:

Upstream primer ITS1: 5'-TCCGTAGGTGAACCTGCGG-3'; Downstream primer ITS2: 5'-TCCTCCGCTTATTGAT ATGC-3'

b) PCR system

Ultra-pure water: $19 \mu \mathrm{L}$

2x Tap Master Mix: $25 \mu \mathrm{L}$

Primer 1: $2 \mu \mathrm{L}$

Primer 2: $2 \mu \mathrm{L}$

Substrate template: $2 \mu \mathrm{L}$ DNA suspension

c) PCR reaction

$96^{\circ} \mathrm{C}$ pre-denaturation: $3 \mathrm{~min}$

$96^{\circ} \mathrm{C}$ (denaturation): $45 \mathrm{~s}$ )

$55^{\circ} \mathrm{C}$ (annealed): $45 \mathrm{~s}$

$72^{\circ} \mathrm{C}$ (extension): $90 \mathrm{~s}$

35 cycles

$72^{\circ} \mathrm{C}$ (extension): $8 \mathrm{~min}$

Then, the PCR products were visualized on agarose gel $(0.8 \%$ in TAE buffer). $0.24 \mathrm{~g}$ agarose powder was weighed and added to $30 \mathrm{~mL} 1 \times$ TAE buffer, and the mixture was heated until boiling. After it had cooled, $1.5 \mu \mathrm{L}$ ethidium bromide was added and mixed. The mixture was then poured into the template to form a glue. Then the glue was put into an electrophoresis tank. $1 \times$ TAE buffer was added over the gel surface, the gel spotted in order, and the power turned on $(130 \mathrm{~V}, 30 \mathrm{~min})$. After running the gel, the ultraviolet imaging was observed in the gel imaging system.

The PCR products were then sent to General Biosystems Co., Ltd for strain identification. The ITS rDNA sequence of the isolated strain was compared with the ITS rDNA sequence recorded in NCBI by Blast, and strains with homology similarity above $95 \%$ were selected to construct a phylogenetic tree.

\section{Extraction and Purification of RDE From the Strain}

The organism suspension above was centrifuged by refrigerated centrifuge at a speed of $8,000 \times \mathrm{g}$ for $45 \mathrm{~min}$, the supernatant was stored at $4^{\circ} \mathrm{C}$ as crude enzyme.

The crude enzyme solution was precipitated by ammonium sulfate, then ammonium sulfate was slowly added to $60 \%$ saturation, stirring until completely dissolved and resting overnight. After the refrigerated centrifugation at a speed of $8000 \times \mathrm{g}$ for $45 \mathrm{~min}$, the precipitate was discarded and the supernatant was then slowly added with ammonium sulfate to $90 \%$ saturation, stirred until dissolved and rested overnight. The above refrigerated centrifugation $(8,000 \times \mathrm{g}, 45 \mathrm{~min})$ was repeated, the supernatant discarded, and the precipitate added to $60 \mathrm{~mL}$ acetic acid buffer solution $(0.02 \mathrm{M}, \mathrm{pH}=5)$ to make a suspension. Finally, the suspension was transferred to a dialysis bag (shanghai yuanye Bio-Technology Co., Ltd. interception molecular weight of 4,000 ) and dialyzed against $4^{\circ} \mathrm{C}$ distilled water overnight.

\section{Enzyme Activity Determination Enzyme Activity Determination of Free-RDE}

The crude enzyme was taken as free-RDE, $55 \mu \mathrm{L}$ of which was added to $1 \mathrm{~mL}$ of $80 \%$ ChGly-water containing rutin $\left(1 \mathrm{mg} \mathrm{mL}^{-1}\right)$ and adjusted the $\mathrm{pH}$ to 7 . The mixture was incubated at $37^{\circ} \mathrm{C}$ for $15 \mathrm{~min}$. The reaction was stopped by adding $1 \mathrm{~mL}$ of methanol. The amount of degraded rutin was determined by HPLC as described in a former study (Zang et al., 2020).

One unit of RDE activity was defined as the amount of enzyme required to catalyze $1 \mu \mathrm{g}$ rutin per min under the conditions above.

\section{Protein Content Determination of Free-RDE}

The protein content of free-RDE was determined using the Bradford method, BSA was used to prepare standard solution (0.005-0.025 mg mL $\left.\mathrm{mg}^{-1}\right)$, its UV absorbance at $595 \mathrm{~nm}$ was measured to establish a standard curve.

\section{Enzyme Activity Determination of CLEA-RDE}

The enzyme activity of CLEA-RDE was determined by the above method. The enzyme activity unit of CLEA-RDE was also defined as above.

Recovery rate of CLEA-RDE activity (\%) = CLEA-RDE activity / total activity of free-RDE added $\times 100 \%$.

\section{Preparation and Optimization of CLEA-RDE}

\section{Preparation of CLEA-RDE}

$0.1 \mu \mathrm{g}$ bovine serum albumin (BSA) was slowly added in $4.9 \mathrm{~mL}$ of dialyzed enzyme solution diluted 20 -fold with acetate buffer $\left(0.02 \mathrm{~mol} \mathrm{~L}^{-1}, \mathrm{pH}=5\right)$ for precipitation, and rested at room temperature for $30 \mathrm{~min}$. Twenty-five percentage glutaraldehyde solution was then slowly added to a concentration of $0.5 \%(\mathrm{v} / \mathrm{v})$. Cross-linking was applied at $20^{\circ} \mathrm{C}$ for $3 \mathrm{~h}$ with continuous gentle stirring, and after being centrifuged $\left(4^{\circ} \mathrm{C}, 8,000 \times \mathrm{g}, 45 \mathrm{~min}\right)$ the precipitates were washed by acetate buffer $\left(0.02 \mathrm{~mol} \mathrm{~L}^{-1}\right.$, $\mathrm{pH}=5) 3$ times and were collected and then suspended with a $4 \mathrm{ml}$ Tris- $\mathrm{HCl}$ buffer.

\section{Optimization of Immobilization Conditions of CLEA-RDE}

Six factors were selected, namely: cross-linking agent concentration $(0.5 \%, 1 \%, 1.5 \%, 2 \%, \mathrm{v} / \mathrm{v}), \mathrm{pH}(4,5,6,7,8$, $9)$, time $(1,2,3,4 \mathrm{~h})$, BSA amount $(0,0.5,1,5,10 \mu \mathrm{g})$, dilution factor of enzyme solution $(0,20,50,100,200)$, and temperature 
$\left(5,20,30,40,50^{\circ} \mathrm{C}\right)$. These were tested one factor at a time, and the rutin degraded amount was determined using the method above.

Based on the results of the single factor test (Figure S1), an orthogonal L9 $(3)^{3}$ test was designed (Table S1) to optimize the immobilization conditions of CLEA-RDE. Factors were dilution factor of the enzyme solution, temperature, $\mathrm{pH}$ and cross-linking agent concentration. The immobilized enzyme activity was the dependent variable.

\section{Structure Characterization of CLEA-RDE}

The surface structure of the freeze-dried CLEA-RDE and freeRDE was observed under a vacuum with a S-4800 field emission scanning electron microscope (Hitachi, Ltd.). The infrared spectrum changes of RDE before and after cross-linking were analyzed in the range of wavelength $4,000-400 \mathrm{~cm}^{-1}$ with a resolution of 4, scanning time of 32 by IR200 Fourier transform infrared spectrometer (FTIR) (Nicolet Co., Ltd.). A L20A UV spectrophotometer (SHIMADZU Co., Ltd.) was used to scan the $\mathrm{RDE}$ at full wavelength to analyze the change of the maximum absorption wavelength.

\section{Optimization of Hydrolysis Conditions of CLEA-RDE}

As a protein, the catalytic activity of CLEA-RDE is often affected by the temperature, time and $\mathrm{pH}$ of the reaction system. At the same time, the ratio of enzyme and reaction substrate in the system also affects the yield of the hydrolysis reaction. After immobilization, the structural and physicochemical properties of the enzyme protein were changed compared to the free enzyme, and the optimal reaction conditions need to be redesigned to explore the experiment.

CLEAs amount $(55,100,150,200 \mu \mathrm{L}), \mathrm{pH}(4,5,6,7,8,9)$, time $(5,15,30,45,60 \mathrm{~min})$, and temperature $\left(20,40,60,80^{\circ} \mathrm{C}\right)$ were selected to establish single factor experiments. One factor at a time was tested, and the rutin degraded amount was determined using the method above.

According to the results of the single factor tests (Figure S2), 3 factors (time, $\mathrm{pH}$, temperature) were selected for further optimization. The immobilized enzyme activity was the dependent variable. The design of the orthogonal experiment is shown in Table S2.

\section{Study on Enzymatic Properties of CLEA-RDE \\ Effect of Temperature on the Catalytic Activity of CLEA-RDE}

Determination of optimum reaction temperature: the activity determination was performed at $20,30,40,50,60$, and $70^{\circ} \mathrm{C}$.

Determination of the thermal stability of enzymes: the enzyme was incubated at $20,30,40,50,60$, and $70^{\circ} \mathrm{C}$ for $2 \mathrm{~h}$ before activity assay.

\section{Effect of $\mathrm{pH}$ on the Catalytic Activity of CLEA-RDE}

Determination of optimum reaction $\mathrm{pH}$ : the enzyme activity was determined in the system with $\mathrm{pH} 4-8$.
Determination of the $\mathrm{pH}$ stability of enzymes: the enzyme was incubated in the system of $\mathrm{pH} 4-8$ for $2 \mathrm{~h}$ before activity assay.

\section{Effect of Organic Solvents on the Catalytic Activity of CLEA-RDE}

Eighty percentage dimethyl sulfoxide, methanol, ethanol and chloroform were used to determine the activity of RDE before and after cross-linking, and the enzyme activity recovery rate was calculated.

\section{Determination of Enzymatic Kinetic Parameters}

Catalytic rate of free-RDE and CLEA-RDE was determined with $0.1,0.2,0.3,0.4,0.5$, and $0.6 \%$ substrate solutions at the time of $1.5 \mathrm{~min}$ by the way above. $1 /[\mathrm{s}]$ and $1 /[\mathrm{r}]$ were taken to establish a coordinate system, draw a Lineweaver-Burk curve, and calculate $K_{\mathrm{m}}$ and $\mathrm{V}_{\max }$ from the slope and intercept.

\section{Reuse and Storage Stability of CLEA-RDE and Free-RDE}

The stability of CLEA-RDE during batch reactions was investigated. After each batch reaction (reaction conditions: 55 $\mu \mathrm{L}$ CLEA-RDE; $1 \mathrm{~mL} \mathrm{80 \%} \mathrm{ChGly-water} \mathrm{containing} 1 \mathrm{mg} \mathrm{mL}{ }^{-1}$ rutin; $\left.\mathrm{pH}=7 ; 37^{\circ} \mathrm{C} ; 15 \mathrm{~min}\right)$, the catalyst was recovered by filtration and used again in a fresh reaction mixture to determine the conversion. The residual activity of each batch was calculated by setting the enzyme activity of the first batch as $100 \%$.

The storage stability of CLEA-RDE and free-RDE were determined at $25^{\circ} \mathrm{C}$ and $4^{\circ} \mathrm{C}$. The initial activity of CLEA-RDE determined just after preparation was set as $100 \%$. The activity was measured every month.

\section{RESULT AND DISCUSSION}

\section{Strain Screening Results} Identification of Strain Activity

A strain of fungus (F1) and a strain of bacteria (B1) were domesticated with the conversion of 53.9 and $2.4 \%$, respectively. Thus, strain F1 with high catalytic activity was further identified and used as the subject of subsequent experimental research.

\section{Morphological and Molecular Biology Identification}

The colony identification was obtained from Figure S1A. The strain F1 was round on the culture medium, with flat colonies and cotton-fiber-shaped white hyphae. Microscopic observation was displayed in Figure S1B. The mycelium had a septum and branches, producing long tube-shaped arthrospores. According to GB 4789.16-2016 (GB 4789.16-2016, 2017), the strain was initially identified as Fusarium spp, and the aerial hyphae could develop on potato-glucose agar or Czapek-Dox medium, with various forms of megaconidia such as sickle, linear, and spindle.

The PCR product of strain F1 was verified using $0.8 \%$ agarose gel electrophoresis. Figure $\mathbf{S} 2$ showed that the amplified product had a single band and a fragment size of about $600 \mathrm{bp}$. The band was clear and suitable for sequencing experiment.

According to the sequencing results (Zang et al., 2020) (Figure S3), F1 was identified as Fusarium spp. 


\section{Orthogonal Experiments to Optimize Immobilization Conditions}

CLEA-RDE with an enzyme activity of $3.84 \mathrm{mg} \mathrm{min}^{-1} \mathrm{~L}^{-1}$ was obtained through immobilization, and its activity recovery rate was $20.36 \%$. To optimize the immobilization conditions, single factor test was set up. Orthogonal experiments were designed according to the single factor test (Figure S4). Glutaraldehyde was the most commonly used cross-linking agent in the preparation of CLEAs which greatly affected the immobilization rate (Razib et al., 2020). The cross-linking of glutaraldehyde to the enzyme was mainly through the covalent bonding between the aldehyde groups at both ends and the $\alpha$-lysine on the surface of the enzyme molecule to obtain insoluble cross-linked enzyme aggregates. When the concentration of the cross-linking agent was too low, cross-linking failed to occur; when the concentration was too high, cross-linking between enzyme molecules and intramolecules closely interconnected, and glutaraldehyde might even bind to the enzyme active center, resulting in a decrease in enzyme activity. The effect of cross-linker concentration on immobilization was presented in Figure S4A. It could be seen that the immobilization efficiency was the highest when the glutaraldehyde concentration is $0.5 \%$.

As shown in Figure $\mathbf{S 4 B}$, the immobilization efficiency was the highest at $\mathrm{pH} 7$, because the spatial structure, active site and binding site dissociation state of the enzyme varied greatly under different $\mathrm{pH}$ environments. At $\mathrm{pH} 7$, it was the most suitable environment for RDE to form cross-linking with glutaraldehyde.

The effect of different cross-linking time on the immobilization efficiency was displayed in Figure S4C. The immobilization efficiency reached the maximum at $3 \mathrm{~h}$, then excessive cross-linking occurred and the enzyme activity decreased.

The effect of the BSA addition on the immobilization efficiency was depicted in Figure S4D. The immobilization efficiency was the highest when the concentration of BSA was $1 \mathrm{mg} \mathrm{mL}{ }^{-1}$, and then decreased with the increment of BSA concentration. It has been proved that the addition of BSA can provide the amino acid groups required for complete crosslinking, thus improving the activity, stability (Cui et al., 2012) and separation of CLEA (Razib et al., 2020), But notably, excess BSA would compete with RDE and inhibit the cross-linking. Results in this study were also consistent with this conclusion.

Figure S4E showed that the amount of enzyme added also had an effect on the enzyme activity. The activity of cross-linking enzyme increased first with the increasing amount of enzyme, and then decreased after reaching the maximum value. This was because the number of cross-linking groups of glutaraldehyde was limited, after the saturation value was exceeded, the amount of enzyme continued to increase, resulting in a decrease in immobilization stability. At the same time, an increase in the concentration of the enzyme also caused an increase in the volume of the aggregate to cause diffusion restrictions, leading to the difficult combination between the substrate and enzyme active center and therefore reducing the enzyme activity. Here the best immobilization efficiency was achieved when the dilution ratio of the enzyme solution is 50 times.
Figure S4F demonstrated that the immobilization efficiency was the highest at $20^{\circ} \mathrm{C}$, and the temperature affected the molecular structure of the protein and the cross-linking of the enzyme.

According to the results above, dilution factor of the enzyme solution, temperature, $\mathrm{pH}$ and cross-linking agent concentration were further optimized (Table S1). The results were shown in Table 1. As presented in Table 1, the factors affecting the immobilization of RDE were as follows, with a decreasing order: cross-linking agent concentration, dilution factor of the enzyme solution, $\mathrm{pH}$ and temperature. Combined with the results of the single factor test, the optimal immobilization conditions were: the crude enzyme solution was diluted for 20 times, $0.1 \mu \mathrm{g}$ BSA added, stood at room temperature for $30 \mathrm{~min}$, and then $25 \%$

\begin{tabular}{|c|c|c|c|c|c|}
\hline & $\begin{array}{c}\text { Dilution factor } \\
\text { of the enzyme } \\
\text { solution }\end{array}$ & $\begin{array}{c}\text { Temperature } \\
\left({ }^{\circ} \mathbf{C}\right)\end{array}$ & $\mathrm{pH}$ & $\begin{array}{l}\text { Cross-linking } \\
\text { agent } \\
\text { concentration }\end{array}$ & $\begin{array}{l}\text { Degradation rate } \\
\left(\mathrm{mg} \min ^{-1} \mathrm{~L}^{-1}\right)\end{array}$ \\
\hline 1 & 20 & 4 & 6 & $0.25 \%$ & 8.01 \\
\hline 2 & 20 & 20 & 7 & $0.5 \%$ & 5.00 \\
\hline 3 & 20 & 30 & 8 & $0.75 \%$ & 4.59 \\
\hline 4 & 50 & 4 & 7 & $0.75 \%$ & 4.70 \\
\hline 5 & 50 & 20 & 8 & $0.25 \%$ & 6.49 \\
\hline 6 & 50 & 30 & 6 & $0.5 \%$ & 5.37 \\
\hline 7 & 100 & 4 & 8 & $0.5 \%$ & 3.91 \\
\hline 8 & 100 & 20 & 6 & $0.75 \%$ & 4.43 \\
\hline 9 & 100 & 30 & 7 & $0.25 \%$ & 6.12 \\
\hline $\mathrm{K}_{1}$ & 5.87 & 5.54 & 5.94 & 6.87 & - \\
\hline $\mathrm{K}_{2}$ & 5.52 & 5.31 & 5.27 & 4.76 & - \\
\hline $\mathrm{K}_{3}$ & 4.82 & 5.36 & 5.00 & 4.58 & - \\
\hline$R_{j}$ & 1.05 & 0.23 & 0.94 & 2.30 & - \\
\hline
\end{tabular}

a Standard degradation conditions: $55 \mu \mathrm{L}$ CLEA-RDE, $1 \mathrm{~mL} 80 \%$ ChGly with $1 \mathrm{mg} \mathrm{mL}^{-1}$ rutin content, $37^{\circ} \mathrm{C}, 15 \mathrm{~min}$.

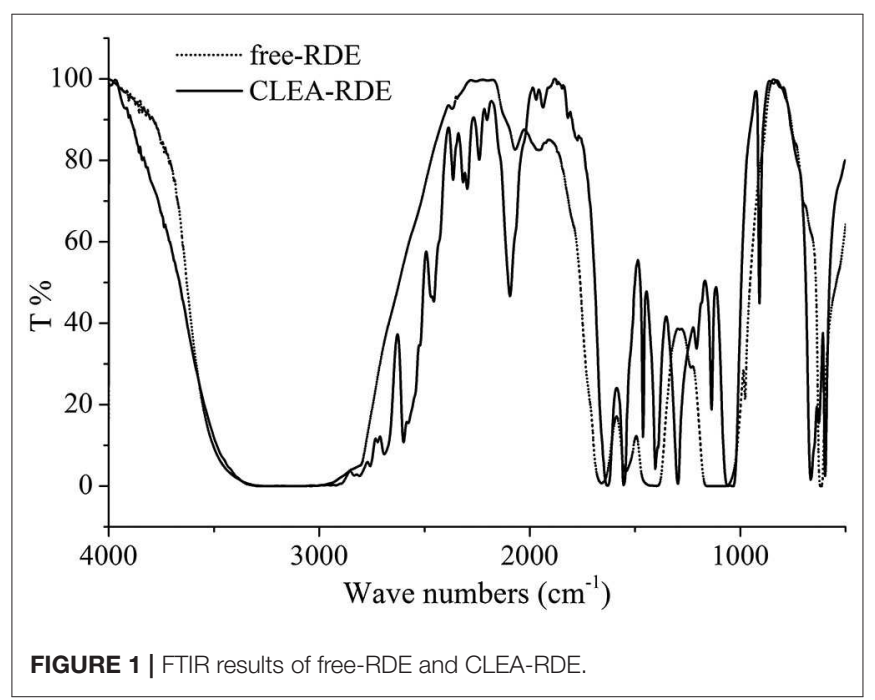


glutaraldehyde solution slowly added to a final concentration of $0.25 \%$. The $\mathrm{pH}$ of the action system was altered to 6 , and crosslinked at $4^{\circ} \mathrm{C}$ for $3 \mathrm{~h}$ with continuous gentle stirring. After the centrifugation, the precipitates were washed and dissolved to obtain CLEA-RDE. Three parallel experiments were performed with a degradation rate of $8.16 \mathrm{mg} \mathrm{min}^{-1} \mathrm{~L}^{-1}$.

\section{Structural Characterization of CLEA-RDE}

According to the FTIR results from Figure 1, there was a strong peak at $1500 \mathrm{~cm}^{-1}$ of CLEA-RDE compared to free-RDE, which indicated that there were more amide bonds formed by the reaction of amino groups and aldehyde groups in the aggregate. It verified that CLEA-RDE formed a tightly structured cross-linked enzyme aggregate through the cross-linking of glutaraldehyde.

Schoevaart et al. (2004) conducted an SEM of the structure of 12 kinds of CLEAs and found that the structure of different enzyme aggregates could be divided into two types: I highly hydrophobic with no glycosylation on the surface, II highly hydrophilic and glycosylated on the surface. From Figure 2, we could figure out that the RDE had significant structural differences before and after cross-linking: the RDE had a large regular spherical structure before cross-linking; after cross-linking, it formed a structure between I and II that was neither a ball nor belonging to a random cross-linked structure. However, the addition of the cross-linking agent caused covalent

TABLE 2 | Design and results of the L9 $\left(3^{3}\right)$ orthogonal test ${ }^{\mathrm{a}}$.

\begin{tabular}{lcccc}
\hline & Time (min) & $\mathbf{p H}$ & $\begin{array}{c}\text { Temperature } \\
\left({ }^{\circ} \mathbf{C}\right)\end{array}$ & $\begin{array}{c}\text { Degradation rate } \\
\left(\mathbf{m g ~ m i n}^{-\mathbf{1}} \mathbf{~ L} \mathbf{- 1}\right)\end{array}$ \\
\hline 1 & 15 & 5 & 40 & 8.58 \\
2 & 15 & 6 & 50 & 4.39 \\
3 & 15 & 7 & 60 & 1.11 \\
4 & 30 & 5 & 50 & 4.81 \\
5 & 30 & 6 & 60 & 0.30 \\
6 & 30 & 7 & 40 & 2.53 \\
7 & 45 & 5 & 40 & 3.56 \\
8 & 45 & 6 & 60 & 1.49 \\
9 & 45 & 7 & 50 & - \\
$\overline{\mathrm{K}}_{1}$ & 4.69 & 5.65 & 4.89 & - \\
$\overline{\mathrm{K}}_{2}$ & 2.55 & 2.06 & 3.46 & - \\
$\overline{\mathrm{K}}_{3}$ & 2.07 & 1.60 & 0.97 & - \\
$\mathrm{R}_{\mathrm{j}}$ & 2.62 & 4.05 & 3.92 & \\
\hline
\end{tabular}

a Standard degradation conditions: $55 \mu \mathrm{L}$ CLEA-RDE, $1 \mathrm{~mL} 80 \%$ ChGly with $1 \mathrm{mg} \mathrm{mL}^{-1}$ rutin content, $37^{\circ} \mathrm{C}, 15 \mathrm{~min}$.

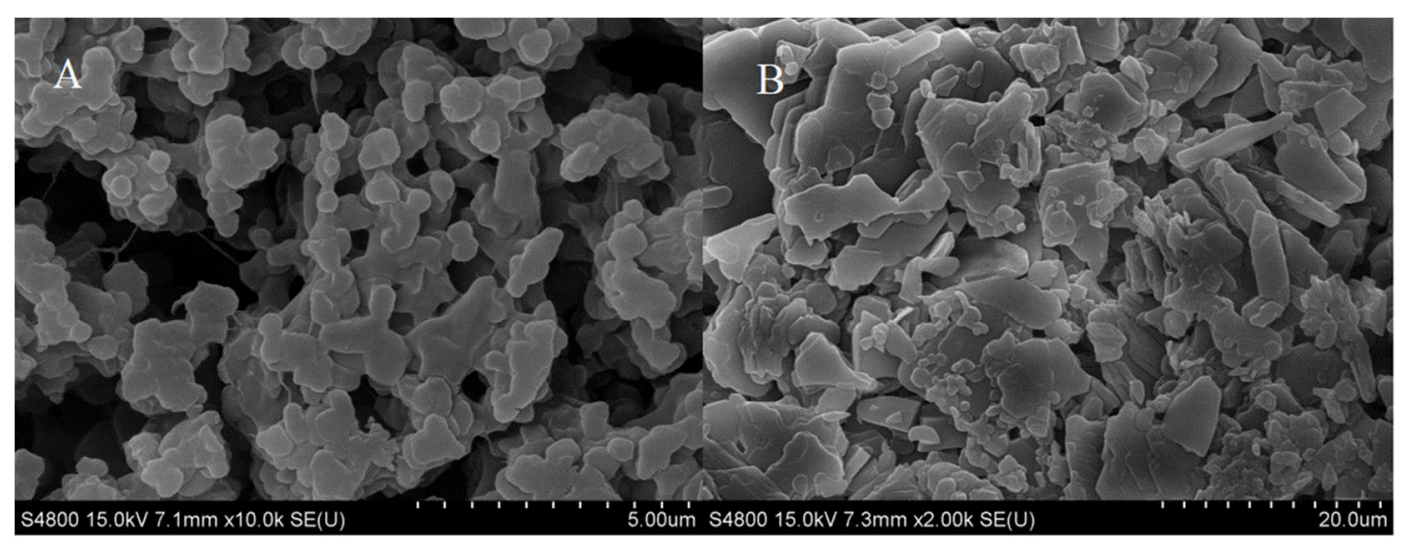

FIGURE 2 | SEM of RDE before and after aggregation [(A) RDE before cross-linking; (B) CLEA-RDE].

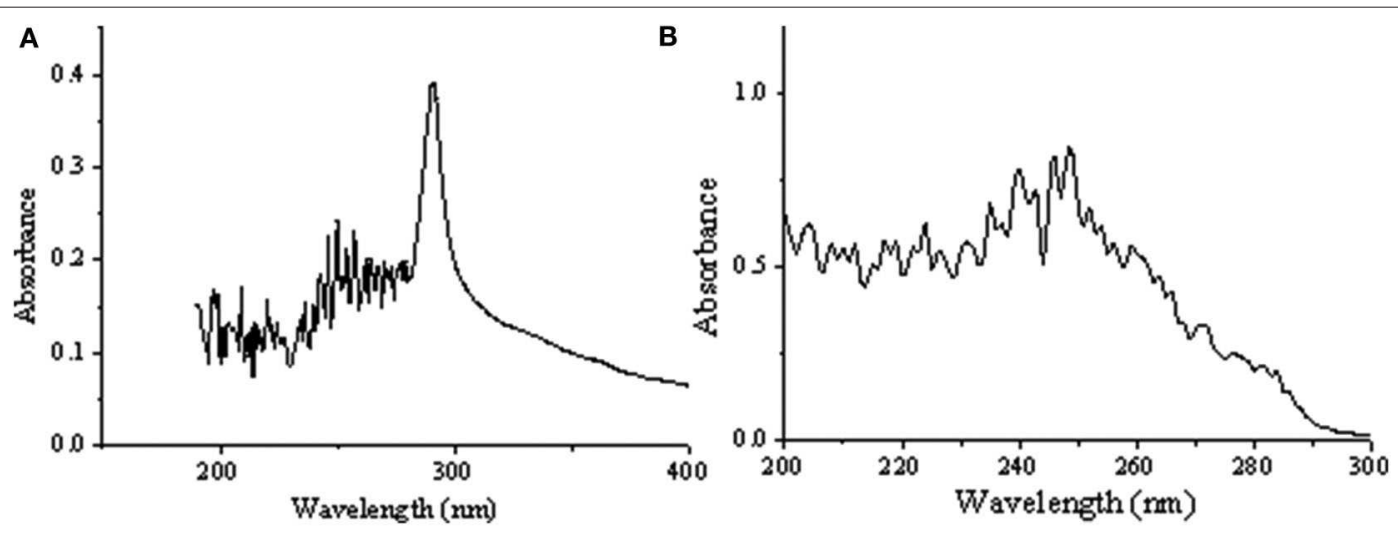

FIGURE 3 | UV full wavelength scanning of free-RDE and CLEA-RDE [(A) free-RDE; (B) CLEA-RDE]. 
bonding in the aggregates, and the stability and mechanical strength of the RDE were improved.

Figure 3 displayed that the maximum absorption wavelength of RDE changed significantly before and after cross-linking. The maximum absorption wavelength of free-RDE (protein content $21.93 \mu \mathrm{g} \mathrm{mL}^{-1}$ ) was $290 \mathrm{~nm}$, a characteristic absorption peak of protein, while the maximum absorption wavelength of CLEARDE moved toward the short-wave direction. It was speculated that this blue shift might be caused by the introduction of a conjugated system into the amide bond.

\section{Orthogonal Experiments to Optimize Hydrolysis Conditions}

According to Figure S5A, when the amount of CLEA-RDE was in the range of $55-200 \mu \mathrm{L}$, the amount of rutin degradation decreased with the increasing amount of enzyme.

The effect of $\mathrm{pH}$ value in the reaction system on the amount of rutin degradation could be seen in Figure S5B. In the range of $\mathrm{pH} 4-9$, the amount of rutin degradation increased first and then decreased as the $\mathrm{pH}$ was increasing. The maximum value appeared at $\mathrm{pH}$, which meant that under the reaction system, the RDE had the highest enzyme activity at $\mathrm{pH} 6$.

The effect of reaction time on the amount of rutin degradation was described in Figure S5C. With the increase of the reaction

TABLE 3 | Stability of CLEA-RDE and free-RDE in different organic reagents ${ }^{\mathrm{a}}$.

Organic solvents LogP Residual enzyme activity Residual enzyme activity of CLEA-RDE (\%)

of free-RDE (\%)

\begin{tabular}{lccc}
\hline Dimethyl sulfoxide & -1.3 & 6.26 & 2.68 \\
Methyl alcohol & -0.76 & 9.46 & 7.96 \\
Ethyl alcohol & -0.24 & 121.68 & 66.32 \\
Trichloromethane & 2.0 & 180.01 & 102.43
\end{tabular}

aStandard degradation conditions: $55 \mu L$ CLEA-RDE or free-RDE solution, $1 \mathrm{~mL} 80 \%$ ChGly with $1 \mathrm{mg} \mathrm{mL}^{-1}$ rutin content, $37^{\circ} \mathrm{C}, 15 \mathrm{~min}$.

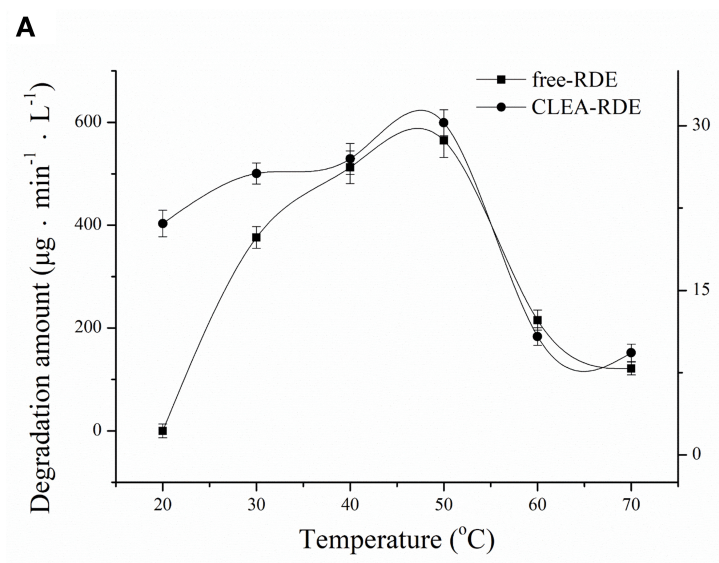

B

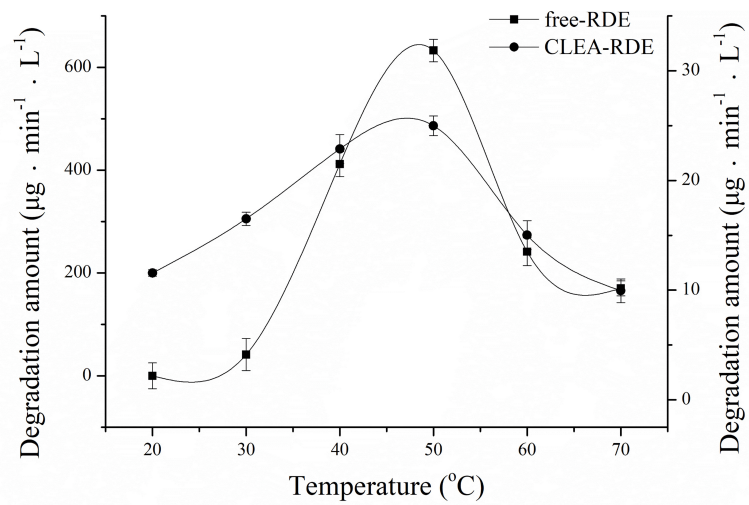

FIGURE 4 | Effect of temperature on the stability (A) and activity (B) of free-RDE and CLEA-RDE. Standard degradation conditions: $55 \mu L$ CLEA-RDE or free-RDE solution, $1 \mathrm{~mL} 80 \%$ ChGly with $1 \mathrm{mg} \mathrm{mL}^{-1}$ rutin content, $37^{\circ} \mathrm{C}, 15 \mathrm{~min}$.

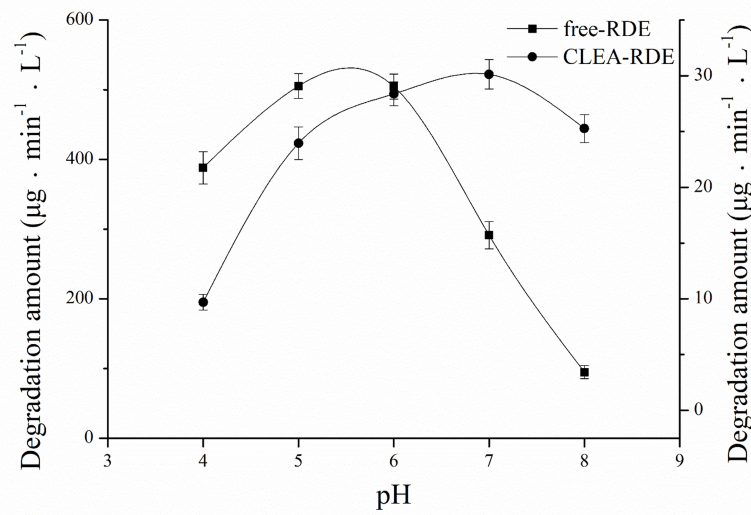

B

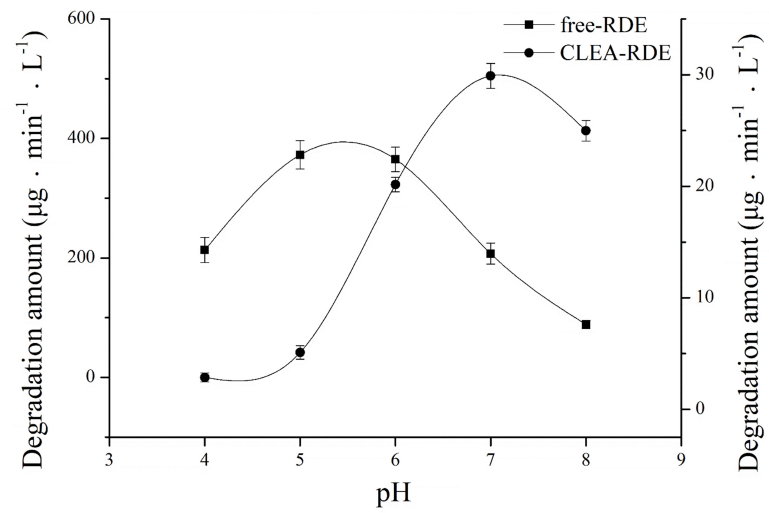

FIGURE 5 | Effect of pH on the stability (A) and activity (B) of free-RDE and CLEA-RDE. Standard degradation conditions: $55 \mu L$ CLEA-RDE or free-RDE solution, $1 \mathrm{~mL} 80 \%$ ChGly with $1 \mathrm{mg} \mathrm{mL}^{-1}$ rutin content, $37^{\circ} \mathrm{C}, 15 \mathrm{~min}$. 


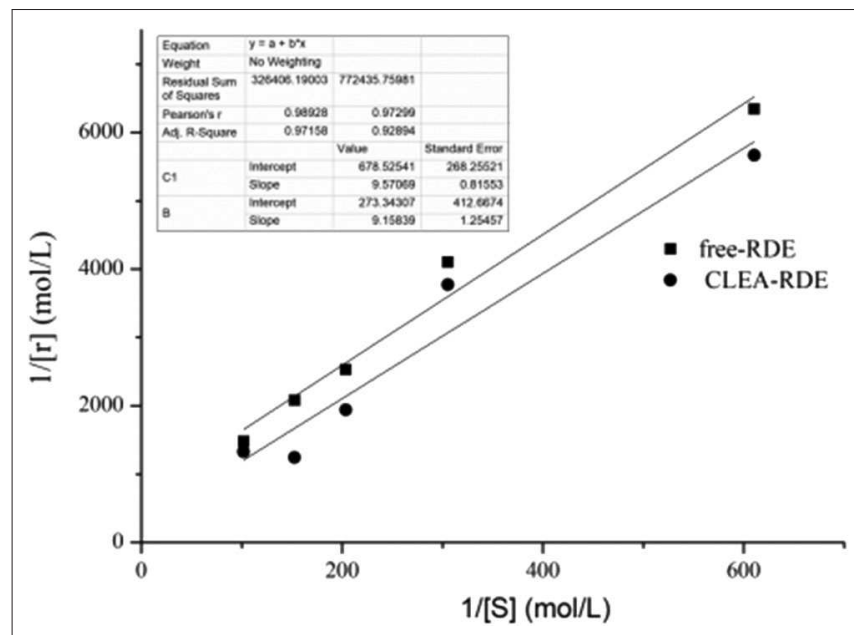

FIGURE 6 | Lineweaver-Burk plot of free-RDE and CLEA-RDE. Standard degradation conditions: $55 \mu \mathrm{L}$ CLEA-RDE or free-RDE solution, $1 \mathrm{~mL}$ rutin- $80 \%$ ChGly of different rutin concentration. $37^{\circ} \mathrm{C}, 1.5 \mathrm{~min}$.

time, the amount of degradation increased, and the maximum value remained stable at about $30 \mathrm{~min}$, that is, the reaction was completed in this reaction system.

Temperature is one of the important factors affecting the activity of enzyme protein. As shown in Figure S5D, in the range of $40-80^{\circ} \mathrm{C}$, the maximum amount of rutin degradation appeared at about $60^{\circ} \mathrm{C}$ as the temperature increased, and then the enzyme activity began to decrease. That meant in this study, $60^{\circ} \mathrm{C}$ was the optimal temperature for CLEA-RDE to exert enzyme activity in the experimental system described herein.

Orthogonal experiments were designed according to the single factor experiment (Table S2). The reaction time, $\mathrm{pH}$, and temperature were further optimized, and the degradation amount of rutin were used as the comprehensive inspection index. The optimization results were shown in Table 2. From the $R_{j}$ value in Table 2 , the influence of various factors on the experimental results could be obtained. The $\mathrm{pH}$ of the reaction system had the largest effect on the degradation of rutin, followed by temperature, and the reaction time had the least effect on the catalytic yield. According to the $\mathrm{K}$ value, the optimal level combination under each factor was selected as the optimal reaction conditions: the $\mathrm{pH}$ of the reaction system was 5 , the reaction time was $15 \mathrm{~min}$, and the reaction temperature was $40^{\circ} \mathrm{C}$. Under the optimal conditions, three verification tests were performed to obtain a degradation rate of $10.65 \mathrm{mg} \mathrm{min}^{-1} \mathrm{~L}^{-1}$.

\section{Study on Enzymatic Properties of CLEA-RDE}

Thermal Properties of CLEA-RDE

The comparison of the thermal stability of CLEA-RDE and free-RDE was described in Figure 4A. CLEA-RDE remained stable in the temperature range of 20 to $50^{\circ} \mathrm{C}$, and notably, the stability was improved at low temperature $\left(20-30^{\circ} \mathrm{C}\right)$ compared with the free-RDE. And from Figure 4B, the optimal temperature of CLEA-RDE and free-RDE were not much different, both about $50^{\circ} \mathrm{C}$. These results demonstrated that the thermal properties of CLEA-RDE were improved compared to free-RDE, which was also confirmed in the cross-linked enzyme aggregates of penicillin acylase (Pchelintsev et al., 2009).

\section{pH Properties of CLEA-RDE}

As Figure 5A showed, RDE could maintain stability in a wide range of $\mathrm{pH}$ and its resilience to alkaline environments was greatly improved. According to Figure 5B, the most favorable $\mathrm{pH}$ of the CLEA-RDE was 7, and it moved to the direction of alkali compared with the free- $\mathrm{RDE}(\mathrm{pH}=5)$, which was due to the decrease in the conformational flexibility of enzyme explained in former study (Talekar et al., 2013).

\section{Stability of CLEA-RDE to Organic Reagents}

From Table 3, it could be obtained that as the $\log P$ value of the organic reagent increasing, the remaining enzyme activity of CLEA-RDE and free-RDE both increased. But the CLEA-RDE was higher, especially in hydrophobic solvents, and the residual activity of CLEA-RDE (121.7\%) was almost twice that of freeRDE (66.3\%) in ethyl alcohol. These results indicated that the RDE immobilized by cross-linking method had a higher stability in a hydrophobic environment, which was consistent with the cross-linked enzyme aggregates of penicillin acylase (Pchelintsev et al., 2009) and phenylalanine ammonia lyase (Cui et al., 2012).

\section{Determination of Enzymatic Kinetic Parameters}

Enzymatic kinetic parameters were critical characteristic data in enzymatic and metabolic studies. The $K_{\mathrm{m}}$ value was constant for a particular enzyme. The larger the $K_{\mathrm{m}}$ value, the smaller the affinity of the enzyme and the substrate; otherwise, the greater the affinity.

As shown in Figure 6, compared with free-RDE $\left(K_{\mathrm{m}}=1.6 \mathrm{mM}, \mathrm{V}_{\max }=15 \mathrm{mM}\right)$, the $K_{\mathrm{m}}$ value of CLEA$\operatorname{RDE}\left(K_{\mathrm{m}}=34 \mathrm{mM}, \mathrm{V}_{\max }=3.7 \mathrm{mM}\right)$ increased, the $\mathrm{V}_{\max }$ value decreased, and the decrease in affinity with the substrate might be due to the fact that the active center of the CLEA-RDE was covered and the binding to the substrate was hindered.

\section{Reuse and Storage Stability of CLEA-RDE and Free-RDE}

In this study, CLEA-RDE could be used at least 8 times without significant loss of activity (96.2\%), which indicated its strong operational stability.

The storage stability of CLEA-RDE and free-RDE were determined and 3 months later, both free-RDE (94.3\%) and CLEA-RDE (95.7\%) maintained their original activities. The results showed that CLEA-RDE could maintain its high catalytic activity during storage.

\section{CONCLUSIONS}

In this experiment, a new source of RDE was explored by microbial utilization of tartary buckwheat and CLEA-RDE was successfully prepared based on a carrier-free immobilization method. NADESs was proved to be useful for maintaining enzyme activity and stability. Under the optimal reaction conditions (in $1 \mathrm{~mL}$ of rutin concentration of $1 \mathrm{mg} \mathrm{mL}^{-1} 80 \%$ ChGly-water co-solvent, $55 \mu \mathrm{L}$ of CLEA-RDE were added, and the reaction was performed at $40^{\circ} \mathrm{C}$ for $15 \mathrm{~min}$ ), the rate of 
rutin degradation reached $10.65 \mathrm{mg} \mathrm{min}^{-1} \mathrm{~L}^{-1}$. In addition, this carrier-free immobilization way for the preparation of CLEA$\mathrm{RDE}$ was critical to prevent the enzyme activity from loss. Hence these results would have great value for the development of the catalyst manufacturing industry.

\section{DATA AVAILABILITY STATEMENT}

The datasets generated for this study can be found in the NCBI SUB7018537 F1 MT102379.

\section{AUTHOR CONTRIBUTIONS}

Y-YZ and Z-GC contributed conception and design of the study. Y-YZ and SY organized the database and performed the statistical analysis. Y-YZ wrote the first draft of the manuscript. TW and

\section{REFERENCES}

Alinezhad, H., Azimi, R., Zare, M., Ebrahimzadeh, M. A., Eslami, S., Nabavi, S. F., et al. (2011). Antioxidant and antihemolytic activities of ethanolic extract of flowers, leaves, and stems of Hyssopus officinalis L. Var. Angustifolius. Int. J. Food Prop. 16, 1169-1178. doi: 10.1080/10942912.2011.578319

Bian, H., Cao, M., Wen, H., Tan, Z., Jia, S., and Cui, J. (2019). Biodegradation of polyvinyl alcohol using cross-linked enzyme aggregates of degrading enzymes from Bacillus niacin. Int. J. Biol. Macromol. 124, 10-16. doi: 10.1016/j.ijbiomac.2018.11.204

Biesaga, M., Stafiej, A., and Pyrzynska, K. (2007). Extraction and hydrolysis parameters for determination of quercetin in hypericum perforatum. Chromatographia 65, 701-706. doi: 10.1365/s10337-007-0204-Z

Bryjak, J., and Kolarz, B. N. (1998). Immobilization of trypsin on acrylic copolymers. Process Biochem. 33, 409-417. doi: 10.1016/S0032-9592(97)00098-8

Cao, L., Langen, L. V., and Sheldon, R. A. (2003). Immobilized enzymes: Carrier-bound or carrier-free? Curr. Opin. Biotechnol. 14, 387-394. doi: 10.1016/S0958-1669(03)00096-X

Cao, L., Van, R. F., and Sheldon, R. A. (2000). Cross-linked enzyme aggregates: a simple and effective method for the immobilization of penicillin acylase. Org. Lett. 2, 1361-1364. doi: 10.1021/ol005593x

Cui, J., Cui, L., Jia, S., Su, Z., and Zhang, S. (2016). Hybird cross-linked lipase aggregates with magnetic nanoparticles: a robust and recyclable biocatalysis for epoxidation of oleic acid. J. Agric. Food Chem. 64, 7179-7187. doi: 10.1021/acs.jafc.6b01939

Cui, J., Zhao, Y., Tan, Z., Zhong, C., Han, P., and Jia, S. (2017). Mesoporous phenylalanine ammonia lyase microspheres with improved stability through calcium carbonate templating. Int. J. Biol. Macromol. 98, 887-896. doi: 10.1016/j.ijbiomac.2017.02.059

Cui, J. D., and Jia, S. R. (2015). Optimization protocols and improved strategies of cross-linked enzyme aggregates technology: current development and future challenges. Crit. Rev. Biotechnol. 35, 15-28. doi: 10.3109/07388551.2013. 795516

Cui, J. D., Zhang, S., and Sun, L. M. (2012). Cross-linked enzyme aggregates of phenylalanine ammonia lyase: novel biocatalysts for synthesis of L-phenylalanine. Appl. Biochem. Biotechnol. 167, 835-844. doi: 10.1007/s12010-012-9738-0

dong Cui, J., li Cui, L., ping Zhang, S., fei Zhang, Y., guo Su, Z., and hui Ma, G. (2014). Hybrid magnetic cross-linked enzyme aggregates of phenylalanine ammonia lyase from Rhodotorula glutinis. PLoS ONE 9:e97221. doi: 10.1371/journal.pone.0097221

Dordick, J. S. (1989). Enzymatic catalysis in monophasic organic solvents. Enzyme Microb.Technol. 11, 194-211. doi: 10.1016/0141-0229(89)90094-X
Y-QX contributed to manuscript revision, read, and approved the submitted version.

\section{FUNDING}

This work was supported by Jiangsu Agricultural Industry Technology System (JATS-2019-442) and the Priority Academic Program Development of Jiangsu Higher Education Institutions (080-820830).

\section{SUPPLEMENTARY MATERIAL}

The Supplementary Material for this article can be found online at: https://www.frontiersin.org/articles/10.3389/fbioe. 2020.00470/full\#supplementary-material

GB 4789.16-2016. (2017). National Food Safety Standard Food Microbiological Inspection Morphological Identification of Common Toxin-producing Fungi. Beijing: Standards Press of China.

Klibanov, A. M. (1986). Enzymes that work in organic solvents. Chemtechnology 16, 354-359.

Kulkarni, N. H., Muley, A. B., Bedade, D. K., and Singhal, R. S. (2019). Cross-linked enzyme aggregates of arylamidase from Cupriavidus oxalaticus ICTDB921: process optimization, characterization, and application for mitigation of acrylamide in industrial wastewater. Bioprocess Biosyst. Eng. 43, 457-471. doi: 10.1007/s00449-019-02240-4

Liang, S., Wu, X. L., Xiong, J., Zong, M. H., and Lou, W. Y. (2019). Metal-organic frameworks as novel matrices for efficient enzyme immobilization: an update review. Coordin. Chem. Rev. 406:213149. doi: 10.1016/j.ccr.2019.213149

Mateo, C., Palomo, J. M., Van Langen, L. M., Van Rantwijk, F., and Sheldon, R. A. (2004). A new, mild cross-linking methodology to prepare cross-linked enzyme aggregates. Biotechnol. Bioeng. 86, 273-276. doi: 10.1002/bit.20033

Nishimuro, H., Ohnishi, H., Sato, M., Ohnishi-Kameyama, M., Matsunaga, I., Naito, S., et al. (2015). Estimated daily intake and seasonal food sources of quercetin in Japan. Nutrients 7, 2345-2358. doi: 10.3390/nu7042345

Pchelintsev, N. A., Youshko, M. I., and Vedas, V. K. (2009). Quantitative characteristic of the catalytic properties and microstructure of cross-linked enzyme aggregates of penicillin acylase. J. Mol. Catal. B Enzym. 56, 202-207. doi: 10.1016/j.molcatb.2008.05.006

Razib, M. S. M., Rahman, R. N. Z. R. A., Shariff, M. F., and Ali, M. S. M. (2020). Biochemical and structural characterization of cross-linked enzyme aggregates (CLEAs) of organic solvent tolerant protease. Catalysts 10:55. doi: $10.3390 /$ catal10010055

Schoevaart, R., Wolbers, M. W., Golubovic, M., Ottens, M., Kieboom, A. P. G., Van Rantwijk, F., et al. (2004). Preparation, optimization, and structures of cross-linked enzyme aggregates (CLEAs). Biotechnol. Bioeng. 87, 754-762. doi: 10.1002/bit.20184

Simioni, C., Zauli, G., Martelli, A. M., Vitale, M., Sacchetti, G., Gonelli, A., et al. (2018). Oxidative stress: role of physical exercise and antioxidant nutraceuticals in adulthood and aging. Oncotarget 9, 17181-17198. doi: 10.18632/oncotarget.24729

Talekar, S., Joshi, A., Joshi, G., Kamat, P., Haripurkar, R., and Kambale, S. (2013). Parameters in preparation and characterization of cross linked enzyme aggregates (CLEAs). RSC Adv. 3, 12485-12511. doi: 10.1039/c3ra40818c

Talekar, S., Joshi, G., Chougle, R., Nainegali, B., Desai, S., Joshi, A., et al. (2014). Preparation of stable cross-linked enzyme aggregates (CLEAs) of NADHdependent nitrate reductase and its use for silver nanoparticle synthesis from silver nitrate. Catal. Commun. 53, 62-66. doi: 10.1016/j.catcom.2014.05.003

Talekar, S., Vijayraghavan, R., Arora, A., Patti, A. (2020). Greener production of low methoxyl pectin via recyclable enzymatic de-esterification using pectin 
methylesterase cross-linked enzyme aggregates captured from citrus peels. Food Hydrocoll. 108:105786. doi: 10.1016/j.foodhyd.2020.105786

Talekar, S., Waingade, S., Gaikwad, V., Patil, S., and Nagavekar, N. (2012). Preparation and characterization of cross linked enzyme aggregates (CLEAs) of Bacillus Amyloliquefaciens alpha amylase. J. Biochem. Technol. 3, 349-353.

Tischer, W., and Kasche, V. (1999). Immobilized enzymes: crystals or carriers? Trends Biotechnol. 17, 326-335. doi: 10.1016/S0167-7799(99)0 $1322-0$

Turner, C., Turner, P., Jacobson, G., Almgren, K., Waldebäck, M., Sjöberg, P., et al. (2006). Subcritical water extraction and $\beta$-glucosidase-catalyzed hydrolysis of quercetin glycosides in onion waste. Green Chem. 8, 949-959. doi: $10.1039 / \mathrm{B} 608011 \mathrm{~A}$

Ulusoy, H. G., and Sanlier, N. (2019). A minireview of quercetin: from its metabolism to possible mechanisms of its biological activities. Crit. Rev. Food Sci. Nutr. 4, 1-14. doi: 10.1080/10408398.2019.1683810

Wach, A., Krystyna, P., and Biesaga, M. (2007). Quercetin content in some food and herbal samples. Food Chem. 100, 699-704. doi: 10.1016/j.foodchem.2005.10.028

Wei, J. C. (1979). Fungal Identification Handbook. Shanghai: Shanghai Science and Technology Press 495-512.
Yasuda, T., and Nakagawa, H. (1994). Purification and characterization of the rutin-degrading enzymes in tartary buckwheat seeds. Phytochemistry 37, 133-136. doi: 10.1016/0031-9422(94)85012-7

Zaks, A., and Klibanov, A. M. (1984). Enzymatic catalysis in organic media at 100 degrees C. Science 224, 1249-1251. doi: 10.1126/science.6729453

Zang, Y., Chen, Z., Yang, X., and Wu, T. (2020). One-pot preparation of quercetin using natural deep eutectic solvents. Process Biochem. 89, 193-198. doi: 10.1016/j.procbio.2019.10.019

Conflict of Interest: The authors declare that the research was conducted in the absence of any commercial or financial relationships that could be construed as a potential conflict of interest.

Copyright (c) 2020 Zang, Yang, Xu, Chen and Wu. This is an open-access article distributed under the terms of the Creative Commons Attribution License (CC BY). The use, distribution or reproduction in other forums is permitted, provided the original author(s) and the copyright owner(s) are credited and that the original publication in this journal is cited, in accordance with accepted academic practice. No use, distribution or reproduction is permitted which does not comply with these terms. 